\title{
Phospholipid synthesis rates in the eastern subtropical South Pacific Ocean
}

\author{
B. A. S. Van Mooy ${ }^{1}$, T. Moutin ${ }^{2}$, S. Duhamel ${ }^{2,3}$, P. Rimmelin ${ }^{2}$, and F. Van Wambeke ${ }^{3}$ \\ ${ }^{1}$ Dept. of Marine Chemistry and Geochemistry, Woods Hole Oceanographic Institution, MS \#4, Woods Hole, MA 02543, \\ USA \\ ${ }^{2}$ Laboratoire d'Océanographie et de Biogéochimie, UMR-CNRS 6535, Case 901, Centre d'Océanologie de Marseille, \\ Université de la Méditerranée - Campus de Luminy, 13288 Marseille cedex 9, France \\ ${ }^{3}$ Laboratoire de Microbiologie, Géochimie et Ecologie Marines, UMR-CNRS 6117, Case 901, Centre d'Océanologie de \\ Marseille, Université de la Méditerranée - Campus de Luminy, 13288 Marseille Cedex 9, France
}

Received: 17 July 2007 - Published in Biogeosciences Discuss.: 20 Augsut 2007

Revised: 11 December 2007 - Accepted: 4 January 2008 - Published: 6 February 2008

\begin{abstract}
Membrane lipid molecules are a major component of planktonic organisms and this is particularly true of the microbial picoplankton that dominate the open ocean; with their high surface-area to volume ratios, the synthesis of membrane lipids places a major demand on their overall cell metabolism. Specifically, the synthesis of cell membrane phospholipids creates a demand for the nutrient phosphorus, and we sought to refine our understanding of the role of phospholipids in the upper ocean phosphorus cycle. We measured the rates of phospholipid synthesis in a transect of the eastern subtropical South Pacific from Easter Island to Concepcion, Chile as part of the BIOSOPE program. Our approach combined standard phosphorus radiotracer incubations and lipid extraction methods. We found that phospholipid synthesis rates varied from less than 1 to greater than $200 \mathrm{pmol} \mathrm{PL}^{-1} \mathrm{~h}^{-1}$, and that phospholipid synthesis contributed between less than $5 \%$ to greater than $22 \%$ of the total $\mathrm{PO}_{4}^{3-}$ incorporation rate. Changes in the percentage that phospholipid synthesis contributed to total $\mathrm{PO}_{4}^{3-}$ uptake were strongly correlated with the ratio of primary production to bacterial production, which supported our hypothesis that heterotrophic bacteria were the primary agents of phospholipid synthesis. The spatial variation in phospholipid synthesis rates underscored the importance of heterotrophic bacteria in the phosphorus cycle of the eastern subtropical South Pacific, particularly the hyperoligotrophic South Pacific subtropical gyre.
\end{abstract}

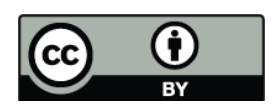

Correspondence to: B. A. S. Van Mooy (bvanmooy@whoi.edu)

\section{Introduction}

Cell membrane lipids form the interface between a cell and its environment, and, as such, house many of the enzyme and transporter systems that are required to harvest energy and material from the environment. Microbial picoplankton (i.e. plankton $<2 \mu \mathrm{m}$ ) have higher cell surface area to cell volume ratios than larger plankton, and therefore we would expect cell membrane lipids to be a particularly important biochemical component of picoplankton. The picoplanktonic community dominates the surface waters of the open ocean (e.g. Cho and Azam, 1990) and is composed of diverse populations of picoeukaryotes, cyanobacteria and heterotrophic bacteria (e.g. Campbell and Vaulot, 1993; Cavender-Bares et al., 2001).

Membrane lipids generally compose 15 to $25 \%$ of the carbon in planktonic cells (Wakeham et al., 1997), and, as such, their synthesis constitutes a substantial fraction of overall community anabolism and carbon demand. The synthesis of one class of membrane lipids, the phospholipids, creates an additional burden to planktonic cells because it creates a demand for nutrient phosphorus. In the surface waters of the North Pacific subtropical gyre (NPSG) the synthesis of phospholipids was shown to consume 18 to $28 \%$ of the $\mathrm{PO}_{4}^{3-}$ taken up by the total planktonic community (Van Mooy et al., 2006). However, the demand for phosphorus created by phospholipid synthesis does not appear to be equally distributed among the various types of plankton that compose the total planktonic community. For example, the synthesis of phospholipids constitutes less than a few percent of overall phosphorus demand by Prochlorococcus, the picocyanobacterium that dominates the phytoplanktonic community of the NPSG and South Pacific subtropical gyre (SPSG) (Björkman et al., 2000; Campbell et al., 1994; Van Mooy et al., 2006; Grob et al., 2007). In addition to phospholipids,

Published by Copernicus Publications on behalf of the European Geosciences Union. 


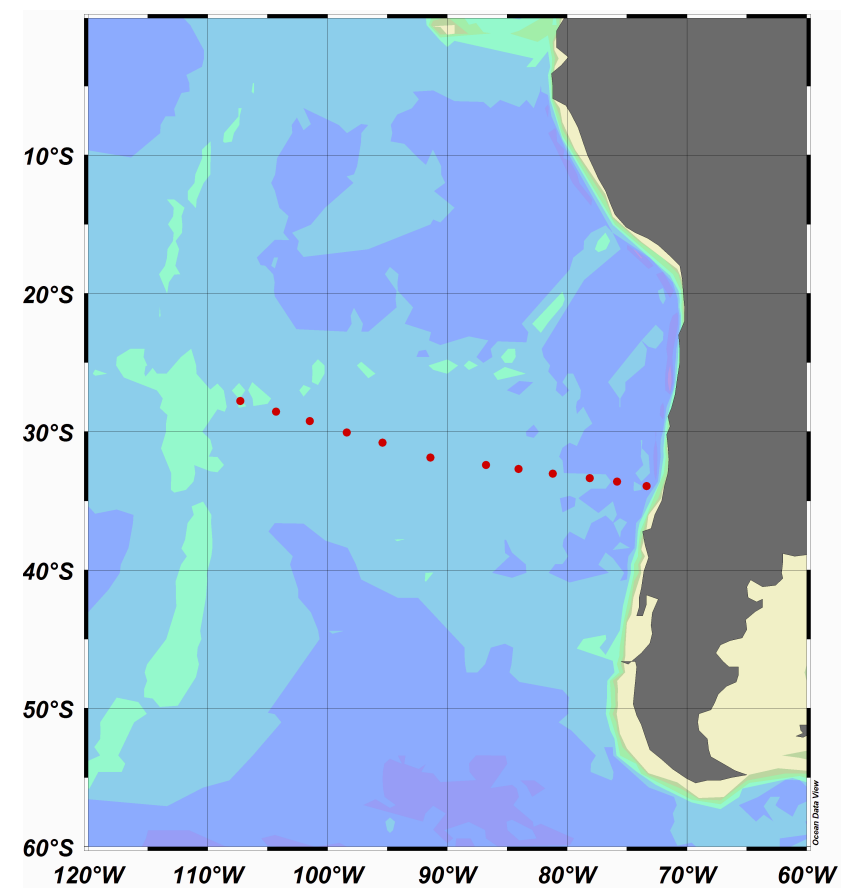

Fig. 1. Map of stations where phospholipid synthesis rates were determined during the second leg of the BIOSOPE cruise.

cyanobacterial membranes also contain abundant glycolipids and sulfolipids (Wada and Murata, 1998). Moreover, these organisms appear to have the ability to substitute sulfolipids for phospholipids when nutrient phosphorus concentrations are low in the environment (Benning, 1998). The observation that sulfolipids were the most abundant membrane lipid in the surface waters of the NPSG, led Van Mooy et al. (2006) to hypothesize that cyanobacteria employ few phospholipids and that heterotrophic bacteria were the organisms primarily responsible for phospholipid synthesis.

We sought to examine the importance of phospholipid synthesis to picoplankton under a range of biological and chemical conditions, with the intention of refining our understanding of the biological origin of phospholipids and the role of phospholipid synthesis within the overall upper ocean phosphorus cycle. We encountered such a range of conditions on the second leg of the BIOSOPE cruise, which was a transect between the hyperoligotrophic waters of SPSG and the nutrient-rich waters upwelled off Chile. We quantified phospholipid synthesis rates at several depths at twelve different stations, and compared these data to chlorophyll fluorescence, primary production rates, and heterotrophic bacterial production rates. These data add further support to the hypothesis that phospholipids are primarily of heterotrophic bacterial origin, and as such, phospholipid synthesis rates are a molecular proxy for the relative role of heterotrophic bacteria in the upper ocean phosphorus cycle.

\section{Methods}

\subsection{Sampling}

Data in this paper were obtained during the second leg of the BIOSOPE cruise between Easter Island and Concepcion, Chile aboard the R/V L' Atalante (Fig. 1; Claustre et al., $\left.2007^{? ?}\right)$. Seawater was collected using Niskin bottles at depths corresponding to either $100,50,15,3,1$ or $0.3 \%$ of surface photosynthetically available radiation (PAR).

\subsection{Incubations}

We collected $250 \mathrm{ml}$ samples of seawater directly from the Niskin bottle into acid-washed polycarbonate bottles. These bottles were then spiked with $0.37 \mathrm{MBq}$ of ${ }^{33} \mathrm{PO}_{4}^{3-}$ (Amersham), which was an amendment of approximately $130 \mathrm{pmol}$ $\mathrm{L}^{-1}$ of ${ }^{33} \mathrm{PO}_{4}^{3-}$ and was less than $1 \%$ of ambient concentrations of $\mathrm{PO}_{4}^{3-}$ at all stations (Moutin et al., 2008; Duhamel et al., 2007). The bottles were then incubated in an on deck incubator at surface seawater temperatures but at in situ PAR. Incubations were started at approximately noon local time and terminated shortly after sundown by filtration on $0.2 \mu \mathrm{m}$ poresize alumina membranes (Whatman).

\subsection{Phospholipid extraction and analysis}

Following filtration, the membranes were immediately immersed in a glass centrifuge tube containing a Bligh and Dyer (1959) extraction mixture, which consisted of $1.5 \mathrm{ml}$ of dichloromethane, $3 \mathrm{ml}$ of methanol and $1.2 \mathrm{ml}$ of $0.1 \mathrm{X}$ phosphate buffered saline (PBS) solution and stored overnight at $-20{ }^{\circ} \mathrm{C}$. The following day, $1.5 \mathrm{ml}$ of dichloromethane and $1.5 \mathrm{ml}$ MilliQ water (Millipore) were added. The samples were centrifuged and the lower organic phase, containing the phospholipids, was recovered. These total phospholipid extracts were used to determine the ${ }^{33} \mathrm{PO}_{4}^{3-}$ uptake rates into the total phospholipids: $500 \mu \mathrm{L}$ of the extract was mixed with $10 \mathrm{~mL}$ of UltimaGold scintillation cocktail (PerkinElmer) in a $20 \mathrm{ml}$ polyethylene scintillation vial. The

${ }^{33} \mathrm{P}$ radioactivity was determined on a Tricarb scintillation counter (Packard) using standard methods (Duhamel et al., 2006).

\subsection{Calculations}

The steady state production rates of phospholipids were determined as follows:

$P=\left(\frac{A / S}{t}\right)$

Where $P$ is the hourly production rate of phospholipids (pmol $\mathrm{PL}^{-1} \mathrm{~h}^{-1}$ ), $A$ is the ${ }^{33} \mathrm{P}$ radioactivity of the phospholipid extract (dpm), $\mathrm{S}$ is the specific ${ }^{33} \mathrm{P}$ radioactivity of $\mathrm{PO}_{4}^{3-}$ in the incubations $\left(\mathrm{dpm}\left(\mathrm{pmol} \mathrm{PL}^{-1}\right)^{-1}\right)$, and $t$ is the 

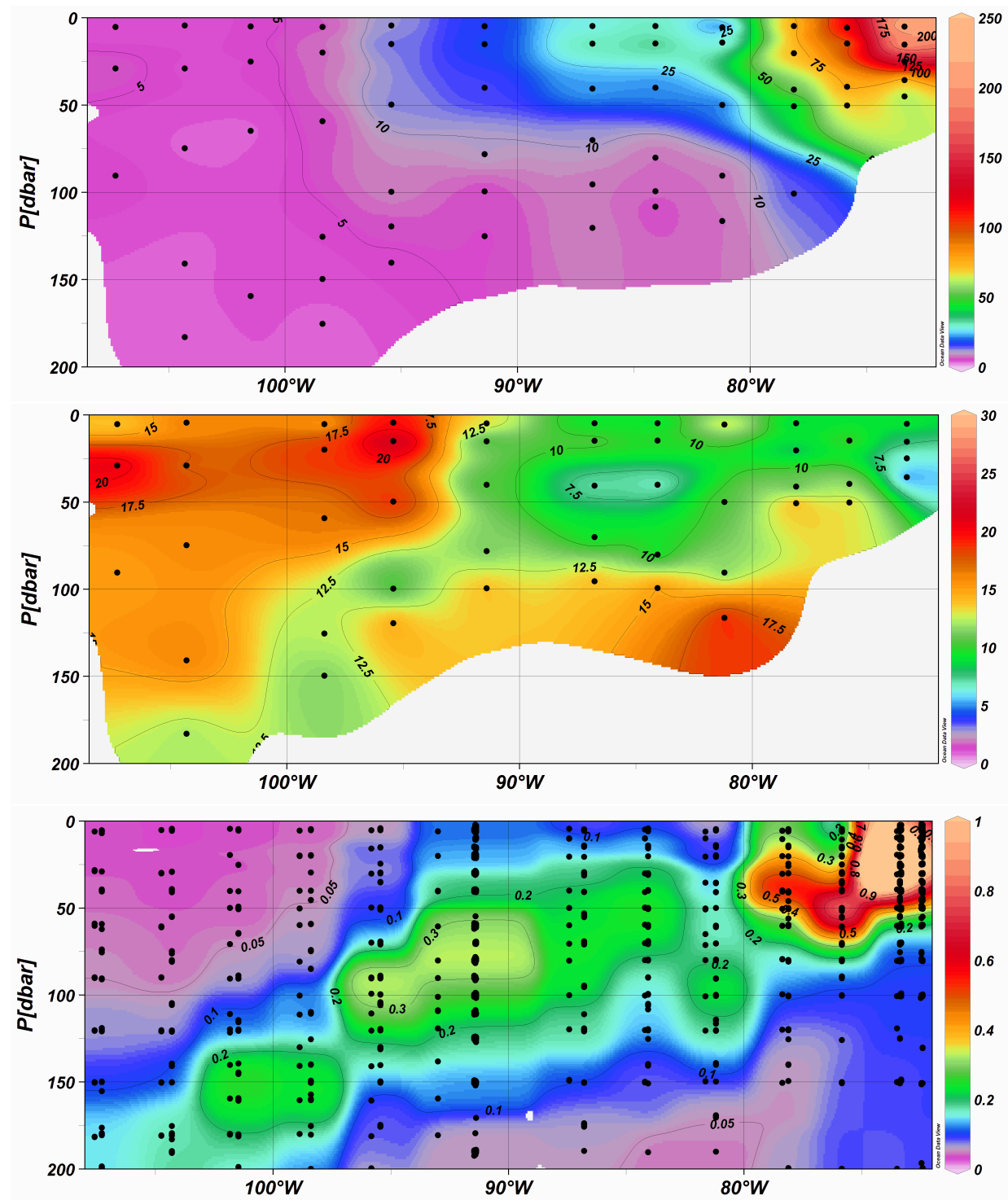

Fig. 2. Northward looking sections between Easter Island and Concepcion, Chile of: (a) phospholipid synthesis rate in units of pmol $\mathrm{PL}^{-1} \mathrm{~h}^{-1}$, (b) contribution of phospholipid synthesis to total $\mathrm{PO}_{4}^{3-}$ incorporation in percent, and (c) in vivo fluorescence in relative units.

length of the incubation (h). The steady-state assumption is valid since the incubation time (approximately $8 \mathrm{~h}$ ) was short compared to the turnover time of $\mathrm{PO}_{4}^{3-}$ (weeks or longer; Moutin et al., 2008). Phosphate concentrations were reported by Moutin et al. (2008). Water from the same Niskin bottles was also used to determine the total $\mathrm{PO}_{4}^{3-}$ incorporation rates using standard methods (Moutin et al., 2008). Contribution of phospholipid production rates to the total $\mathrm{PO}_{4}^{3-}$ incorporation rates were expressed as percent by taking the quotient of the two values and multiplying by 100 . Only one phospholipid synthesis rate measurement was made at each depth, except at $30^{\circ} \mathrm{S} 98^{\circ} \mathrm{W}$ where samples were conducted in trip- licate and coefficient of variation was found to be $6.2 \%$. Data were plotted using Ocean Data View software (Schlitzer, R., Ocean Data View, http://odv.awi-bremerhaven.de, 2004).

\subsection{Additional measurements}

Chlorophyll fluorescence data were obtained in situ using a Chelsea Aquatracka MkIII fluorometer and are expressed in relative units. Heterotrophic bacterial production (BP) hourly rates were determined using ${ }^{3} \mathrm{H}$-leucine incubation and standard microcentrifuge-based protocols as described by Van Wambeke et al. (2007a). Primary production (PP) rates were determined as hourly dissolved inorganic carbon 
uptake rates into particulate material using $\mathrm{H}^{14} \mathrm{CO}_{3}^{-}$incubations as described by Duhamel et al. (2007). Rates of BP, PP and phospholipid synthesis were determined from waters sampled during the same cast and usually from the same Niskin bottles.

\section{Results}

$\mathrm{PO}_{4}^{3-}$ was present in abundance at every station and depth that we examined (Moutin et al., 2008) and was never the nutrient that limited either phytoplanktonic or bacterial production (Bonnet et al., 2007; Van Wambeke et al., 2007b). Concentrations of $\mathrm{PO}_{4}^{3-}$ ranged from 123 to $668 \mathrm{nmol} \mathrm{PL}^{-1}$. Rates of $\mathrm{BP}$ and PP ranged from 3 to $385 \mathrm{ng} \mathrm{C} \mathrm{L}^{-1} \mathrm{hr}^{-1}$ and 9 to $1612 \mathrm{ng} \mathrm{C} \mathrm{L}^{-1} \mathrm{hr}^{-1}$ respectively, and both rates generally decreased with depth and from west to east (Van Wambeke et al., 2007a).

Phospholipid synthesis rates ranged from $1 \mathrm{pmol} \mathrm{PL}^{-1} \mathrm{~h}^{-1}$ in the SPSG to $>200 \mathrm{pmol} \mathrm{PL}^{-1} \mathrm{~h}^{-1}$ off the coast of Chile (Fig. 2a). In general, the phospholipid synthesis rates were relatively constant in the hyperoligotrophic waters west of $98^{\circ} \mathrm{W}$, but increased dramatically eastward of this longitude. Moreover, phospholipid synthesis rates were relatively constant with depth west of $98^{\circ} \mathrm{W}$, but east of this, the rates strongly decreased with depth. When expressed as a percentage of total $\mathrm{PO}_{4}^{3-}$ uptake (Fig. 2b), the phospholipid synthesis rates ranged from $4 \%$ to $23 \%$ of the total $\mathrm{PO}_{4}^{3-}$ uptake rate, with the average being $14 \pm 5 \%$ (mean \pm s.d.; $n=48$ ). Highest percentages were observed in the upper mixed layer of the SPSG, while the lowest rate percentages were observed off the coast of Chile. There was a deep minimum layer in these rate percentages that gradually shoaled between $105^{\circ} \mathrm{W}$ and $90^{\circ} \mathrm{W}$; east of this, minimum values were observed in a layer centered at about $50 \mathrm{~m}$ depth with slightly higher percentages above and markedly higher percentages below. This pattern closely resembled that of chlorophyll fluorescence (Fig. 2c), which showed a maximum layer that shoaled from west to east and centered at about $50 \mathrm{~m}$ east of $90^{\circ} \mathrm{W}$.

\section{Discussion}

During the second leg of the BIOSOPE cruise we encountered a broad range of oceanographic conditions and this was reflected in the phospholipid synthesis rates that we measured, which spanned nearly two orders of magnitude (Fig. 2a). As expected, the rates increased from west to east in conjunction with increasing rates of biomass production (Van Wambeke et al., 2007a). The phospholipid synthesis rates in the SPSG were generally $\leq 5 \mathrm{pmol} \mathrm{PL} \mathrm{L}^{-1} \mathrm{~h}^{-1}$, which is an order of magnitude slower than observed in the NPSG where the rates ranged from 40 to $120 \mathrm{pmol} \mathrm{PL}^{-1} \mathrm{~h}^{-1}$ (Van Mooy and Devol, 2008; Van Mooy et al., 2006). As temperature and $\mathrm{PO}_{4}^{3-}$ availbility are not drastically different be- tween these two locations, We ascribe the difference in phospholipid synthesis rates to the more subdued rates of PP and BP in the SPSG. Thus, phospholipid synthesis rates in the SPSG reflected the extreme hyperoligotrophic conditions in this region (Claustre et al., 2007?? ).

When viewed as a percentage of total $\mathrm{PO}_{4}^{3-}$ uptake, it is clear that phospholipid synthesis was a major component of the upper ocean phosphorus cycle across the entire transect (Fig. 2). However, this was particularly true in the near-surface waters of SPSG, were values in excess of $15 \%$ were consistently observed. So despite the fact that overall phospholipid synthesis rates were an order of magnitude slower in the SPSG than in the NPSG, the relative percentages that phospholipid synthesis contributed to total $\mathrm{PO}_{4}^{3-}$ uptake were very similar to those in the NPSG, which were also in excess of 15\% (Van Mooy et al., 2006). It has been argued that heterotrophic bacteria are the primary source of phospholipids in the NPSG (Van Mooy et al., 2006), and we suggest here that the common percentage of phospholipid synthesis in the NPSG and SPSG reflects the common planktonic community structure of these environments, where heterotrophic bacteria compose the majority of total planktonic cells (Björkman et al., 2000; Campbell et al., 1997; Grob et al., 2007).

We observed a layer where phospholipid synthesis contributed $<15 \%$ of total $\mathrm{PO}_{4}^{3-}$ uptake, which coincided with a layer of maximum chlorophyll fluorescence (Figs. 2b, c). At the station at $92^{\circ} \mathrm{W}$, chlorophyll fluorescence was highest between 50 and $100 \mathrm{~m}$ depth, and Grob et al. (2007) observed maxima in the abundances of picoeukaryotes and Prochlorococcus in this same depth interval. This low contribution of phospholipid synthesis to total $\mathrm{PO}_{4}^{3-}$ incorporation coupled with the abundance of Prochlorococcus suggests that production by phytoplankton contributed disproportionately less to phospholipid synthesis than heterotrophic bacteria. In culture studies, cyanobacteria have been shown to use very little of total $\mathrm{PO}_{4}^{3-}$ uptake for phospholipid synthesis (Cuhel and Waterbury, 1984; Van Mooy et al., 2006). Cyanobacteria and picoeukaryotes are also often very rich in membrane lipids that do not contain phosphorus, such as sulfolipids, glycolipids, and betaine lipids (e.g. Bell and Pond, 1996; Kato et al., 1996; Van Mooy et al., 2006; Wada and Murata, 1998). In the NPSG, RNA synthesis accounted for about half of total $\mathrm{PO}_{4}^{3-}$ uptake and, as such, was a much larger biochemical sink for $\mathrm{PO}_{4}^{3-}$ than phospholipid synthesis (Van Mooy and Devol, 2008; Van Mooy et al., 2006). Thus we interpret the minimum layer in percent phospholipid synthesis as a layer where nucleic acid synthesis by phytoplankton dilutes phospholipid synthesis by heterotrophic bacteria. Further support for this interpretation comes from the data from the below the chlorophyll maximum: due to the decrease in PP with depth the relative contribution of heterotrophic bacteria to total biomass production would presumably be greater below the chlorophyll maximum than at shallower depths, and, 
indeed, phospholipid synthesis contributes a greater percentage of total $\mathrm{PO}_{4}^{3-}$ uptake below the chlorophyll maximum (Fig. 2b).

If phytoplankton did indeed make a disproportionately smaller contribution to phospholipid synthesis than heterotrophic bacteria, then we would expect the percent contribution of phospholipid synthesis to total $\mathrm{PO}_{4}^{3-}$ uptake to have been lowest where phytoplankton contributed the most to overall biomass production. To determine whether this was true, we examined the relationship between the ratio of PP to BP (PP:BP) and the percent contribution of phospholipid synthesis to total $\mathrm{PO}_{4}^{3-}$ incorporation by plotting these data versus one another (Fig. 3); all of these parameters are methodologically independent. We performed a linear regression of the data and found that nearly half of the variance $\left(r^{2}=0.49 ; P<0.01\right)$ in the percent contribution of phospholipid synthesis to total $\mathrm{PO}_{4}^{3-}$ uptake could be explained by the variance in PP:BP. This is a remarkable relationship considering the immense diversity in the populations of both phytoplankton and heterotrophic bacteria across this nearly $3000 \mathrm{~km}$ transect. Furthermore, the relationship is not driven simply by data from the uniquely hyperoligotrophic SPSG portion of the transect, since data points from west of $98^{\circ} \mathrm{W}$ span almost the entire range of values. The $\mathrm{y}$-intercept, where PP:BP is zero, predicts that heterotrophic bacteria alone dedicate $21.1 \pm 8.3 \%$ (mean \pm s.d.) of total $\mathrm{PO}_{4}^{3-}$ uptake to phospholipid synthesis. In contrast, we regressed the data with an inverse first order equation $\left(r^{2}=0.46\right.$; $P<0.01$; not shown) to represent the approach to infinite $\mathrm{PP}: \mathrm{BP}$, and the percent contribution of phospholipid synthesis to total $\mathrm{PO}_{4}^{3-}$ uptake by phytoplankton alone was predicted to be $7.2 \pm 7.7 \%$. This analysis supports our hypothesis that heterotrophic bacteria are a more important source of phospholipid synthesis than phytoplankton. Admittedly, the population differences of the endmember communities probably impact the estimates of percent phospholipid synthesis by phytoplankton and heterotrophic bacteria. For example, the highest ratios of PP:BP occur east of $98^{\circ} \mathrm{W}$ outside of the hyperoligotrophic gyre and outside of the area dominated by Prochlorococcus (Grob et al., 2007), which could explain why the estimate of $7.2 \%$ from the regression is so much higher than the $0.4 \%$ observed in axenic strains of Prochloro-

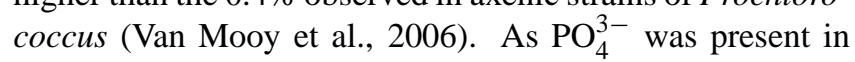
abundance, it is reasonable to expect that phytoplankton were free to employ optimal proportions of phospholipids versus glycolipids and sulfolipids in their membranes. It is important to recognize that the "sulfolipid-phospholipid substitution hypothesis" of Benning (1998) predicts that phytoplankton would have the biochemical motivation to synthesize even fewer phospholipids under conditions where phosphorus is the limiting nutrient, such as in the Mediterranean Sea (Moutin et al., 2002; Thingstad et al., 2005).

Given that heterotrophic bacteria were responsible for the majority of phospholipid synthesis we can use the synthe-

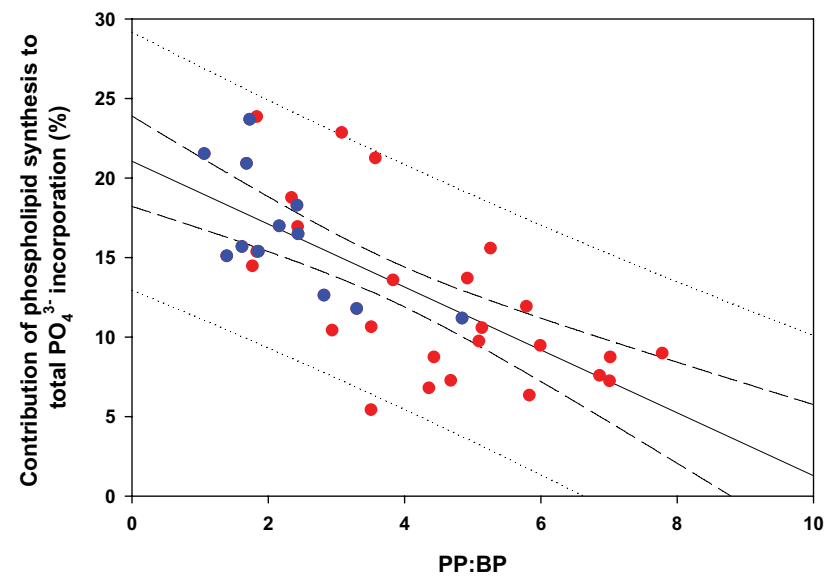

Fig. 3. Plot of percent contribution of phospholipid synthesis to total $\mathrm{PO}_{4}^{3-}$ uptake vs. the ratio of primary production to bacterial production (PP:BP). Blue points are west of $98^{\circ} \mathrm{W}$ and the red points are east of $98^{\circ} \mathrm{W}$. Solid line is linear regression, dashed line is $95 \%$ confidence interval of the regression, and dotted line is $95 \%$ prediction interval.

sis rate data to constrain the role of this group of organisms within the overall phosphorus cycle observed during the BIOSOPE cruise. First, it is clear that heterotrophic bacteria play an important role in the phosphorus cycle of the SPSG, which agrees with Duhamel et al. (2007) who found that plankton $<0.6 \mu \mathrm{m}$ were responsible for the about a third of $\mathrm{PO}_{4}^{3-}$ uptake. Second there were two patches where phospholipid synthesis contributed $<7.5 \%$ of total $\mathrm{PO}_{4}^{3-}$ uptake (Fig. 2b) and these represent areas where phytoplankton production played a more dominant role in the cycling of phosphorus. This type of information has important implications for understanding the distribution of phytoplanktonic vs. bacterial sinks for $\mathrm{PO}_{4}^{3-}$ in the eastern subtropical South Pacific Ocean and, in turn, for understanding sources and sinks of other biolimiting nutrients (e.g. Deutsch et al., 2007). Finally, the phospholipid synthesis data clearly show that heterotrophic bacteria dominated the phosphorus cycle in the lower part of the euphotic zone.

\section{Conclusions}

We found that phospholipid synthesis was a major component of the upper ocean phosphorus cycle during the BIOSOPE cruise. Phospholipid synthesis made the greatest percentage contribution to total $\mathrm{PO}_{4}^{3-}$ incorporation in the surface waters of the SPSG, and the least in the upwelled waters off of Chile. Furthermore, there was a layer in minimum phospholipid synthesis percentage values that corresponded to the layer of maximum chlorophyll concentrations. Regression analyses showed a strong relationship between the variance in phospholipid percentages and variance in PP:BP. These analyses also predicted that heterotrophic bacteria may 
utilize more than a fifth of their total $\mathrm{PO}_{4}^{3-}$ uptake for the synthesis of phospholipids, while phytoplankton may utilize only several percent. Thus phospholipid synthesis is a term in the phosphorus cycle that is dominated by heterotrophic bacteria, and the distribution of the phospholipid synthesis rate during the BIOSOPE cruise confirmed that heterotrophic bacteria play a very important role in the phosphorus cycle of the SPSG.

Acknowledgements. The authors wish to thank the chief scientists of the BIOSOPE cruise H. Claustre and A. Sciandra as well as the captain and crew of the L'Atlante. This is a contribution of the BIOSOPE project of the French LEFE-CYBER program. B. A. S. Van Mooy was funded by the National Science Foundation (OCE-0646944), the Grayce B. Kerr Fund and The Penzance Endowed Fund in Support of Assistant Scientists and the Ocean Life Institute at Wood Hole Oceanographic Institution.

Edited by: S. W. A. Naqvi

\section{References}

Bell, M. V. and Pond, D.: Lipid composition during growth of motile and coccolith forms of Emiliania huxleyi, Phytochemistry, 41, 465-471, 1996.

Benning, C.: Biosynthesis and function of the sulfolipid sulfoquinovosyl diacylglycerol, Annu. Rev. Plant Physiol. Plant Mol. Biol., 49, 53-75, 1998.

Björkman, K., Thomson-Bulldis, A. L., and Karl, D. M.: Phosphorus dynamics in the North Pacific subtropical gyre, Aquat. Microb. Ecol., 22, 185-198, 2000.

Bligh, E. G. and Dyer, W. J.: A rapid method of total lipid extraction and purification, Can. J. Biochem. Physiol., 37, 911-917, 1959.

Bonnet, S., Guieu, C., Bruyant, F., Prasil, O., Raimbault, P., Van Wambeke, F., Gorbunov, M., Zehr, J. P., Grob, C., Masquelier, S., Garczareck, L., and Claustre, H.: Nutrients controlling primary productivity in the South East Pacific (BIOSOPE cruise), Biogeosciences Discuss., 4, 2733-2759, 2007, http://www.biogeosciences-discuss.net/4/2733/2007/

Campbell, L. and Vaulot, D.: Photosynthetic Picoplankton Community Structure in the Subtropical North Pacific-Ocean near Hawaii (Station Aloha), Deep-Sea Res. I, 40, 2043-2060, 1993.

Campbell, L., Nolla, H. A., and Vaulot, D.: The importance of Prochlorococcus to community structure in the central north $\mathrm{Pa}$ cific Ocean, Limnol. Oceanogr., 39, 954-961, 1994.

Campbell, L., Liu, H., Nolla, H. A., and Vaulot, D.: Annual variability of phytoplankton and bacteria in the subtropical North Pacific Ocean at Station ALOHA during the 1991-1994 ENSO event, Deep-Sea Res. I, 44, 167-192, 1997.

Cavender-Bares, K. K., Karl, D. M., and Chisholm, S. W.: Nutrient gradients in the western North Atlantic Ocean: Relationship to microbial community stucture and comparison to patterns in the Pacific Ocean, Deep-Sea Res. I, 48, 2373-2395, 2001.

Cho, B. C. and Azam, F.: Biogeochemical significance of bacterial biomass in the ocean's euphotic zone, Mar. Ecol. Prog. Ser., 63, 253-259, 1990
Cuhel, R. L. and Waterbury, J. B.: Biochemical composition and short term nutrient incorporation patterns in a unicellular marine cyanobacterium, Synechococcus (WH7803), Limnol. Oceanogr., 29, 370-374, 1984.

Deutsch, C., Sarmiento, J. L., Sigman, D. M., Gruber, N., and Dunne, J. P.: Spatial coupling of nitrogen inputs and losses in the ocean, Nature, 445, 163-167, 2007.

Duhamel, S., Zeman, F., and Moutin, T.: A dual-labeling method for the simultaneous measurement of dissolved inorganic carbon and phosphate uptake by marine planktonic species, Limnol. Oceanogr. Meth., 4, 416-425, 2006.

Duhamel, S., Moutin, T., Van Wambeke, F., Van Mooy, B., Rimmelin, P., Raimbault, P., and Claustre, H.: Growth and specific Puptake rates of bacterial and phytoplanktonic communities in the Southeast Pacific (BIOSOPE cruise), Biogeosciences, 4, 913925, 2007,

http://www.biogeosciences.net/4/913/2007/.

Grob, C., Ulloa, O., Claustre, H., Huot, Y., Alarcón, G., and Marie, D.: Contribution of picoplankton to the total particulate organic carbon concentration in the eastern South Pacific, Biogeosciences, 4, 837-852, 2007, http://www.biogeosciences.net/4/837/2007/.

Kato, M., Sakai, M., Adachi, K., Ikemoto, H., and Sano, H.: Distribution of betain lipids in marine algae, Phytochemistry, 42, 1341-1345, 1996.

Moutin, T., Thingstad, T. F., Wambeke, V., Marie, D., Slawyk, G., Raimbault, P., and Claustre, H.: Does competition for nanomolar phosphate supply explain the predominance of the cyanobacterium Synechococcus?, Limnol. Oceanogr., 47, 1562-1567, 2002.

Moutin, T., Karl, D. M., Duhamel, S., Rimmelin, P., Raimbault, P., VanMooy, B. A. S., and Claustre, H.: Phosphate availability and the ultimate control of new nitrogen input by nitrogen fixation in the tropical Pacific Ocean, Biogeosciences, 5, 95-109, 2008, http://www.biogeosciences.net/5/95/2008/.

Thingstad, T. F., Krom, M. D., Mantoura, R. F. C., Flaten, G. A. F., Groom, S., Herut, B., Kress, N., Law, C. S., Pasternak, A., Pitta, P., Psarra, S., Rassoulzadegen, F., Tanaka, T., Tselepides, A., Wassman, P., Woodward, E. M. S., Wexels Riser, C., Zodiatis, G., and Zohary, T.: Nature of phosphorus limitation in the ultraoligotrophic eastern Mediterranean, Science, 309, 1068-1071, 2005.

Van Mooy, B. A. S., Rocap, G., Fredricks, H. F., Evans, C. T., and Devol, A. H.: Sulfolipids dramatically decrease phosphorus demand by picocyanobacteria in oligotrophic marine environments, Proc. Natl. Acad. Sci., 103, 8607-8612, 2006.

Van Mooy, B. A. S. and Devol, A. H.: Assessing nutrient limitation of Prochlorococcus at ALOHA by using an RNA capture method, Limnol. Oceanogr., 53, 78-88, 2008.

Van Wambeke, F., Obernosterer, I., Moutin, T., Duhamel, S., Ulloa, O., and Claustre, H.: Heterotrophic prokaryotic production in the South East Pacific: Longitudinal trends and coupling with primary production, Biogeosciences Discuss., 4, 2761-2791, 2007a.

Van Wambeke, F., Bonnet, S., Moutin, T., Raimbault, P., Alarçon G., and Guieu, C.: Factors limiting heterotrophic prokaryotic production in the southern Pacific Ocean, Biogeosciences Discuss., 4, 3799-3828, $2007 \mathrm{~b}$. 
Wada, H. and Murata, N.: Membrane lipids in cyanobacteria. Lipids in photosynthesis: structure, function and genetics, edited by: Siegenthaler, P.-A. and Murata, N., Kluwer Academic, 65-81, 1998.
Wakeham, S. G., Hedges, J. I., Lee, C., Peterson, M. L., and Hernes, P. J.: Compositions and transport of lipid biomarkers through the water column and surficial sediments of the equatorial Pacific Ocean, Deep-Sea Res. II, 44, 2131-2162, 1997. 